\title{
MONITORIZAREA ȘI GESTIONAREA PROVOCĂRILOR PSIHOLOGICE ÎN SITUAȚII DE DEZASTRU
}

Dr. Róbert ZSÁKAI*

Ne confruntăm zilnic cu știri despre evenimente sociale și politice și dezastre naturale. Acestea au un impact semnificativ atât asupra locuitorilor din zona afectată de dezastru, cât și asupra personalului structurilor de intervenție. Rezultatele cercetărilor au extins cunoștințele de specialitate în ceea ce privește dezastrele naturale și civilizaționale. Pregătirea pentru gestionarea unei situații de criză a evoluat constant într-un sistem de apărare reglementată, care implică protecția valorilor societății. Sarcinile care au legătură cu protecția militară și cele care țin de gestionarea unui dezastru sunt similare, dar pot apărea diferențe cauzale. Gestionarea dezastrelor este, in prezent, un proces foarte complex, care nu reprezintă exclusiv sarcina unei organizații naționale, ci și lupta guvernelor și a organizaților societale pentru un scop comun. Pentru personalul structurilor de intervenție, prelucrarea sarcinilor psihologice de către specialiști devine din ce în ce mai necesară. Rolul autorităților în timpul gestionării situațiilor de urgență este foarte important în ceea ce privește cooperarea actorilor implicați și coordonarea acțiunilor. Necesitatea rolului de sprijin al organizațiilor umanitare internaționale și naționale este, de asemenea, consolidată. Această lucrare ișsi propune să expună elementele de evaluare a riscului și a rezilienței oamenilor în situații de dezastru, pentru înțelegerea vulnerabilităților, iar rezultatele evaluării ar trebui incluse în măsurile pentru planificarea de urgență.

Cuvinte-cheie: dezastru; crizăa asistență psihologică ; PTSD; managementul apărării.

* Slt. dr. Róbert ZSAKKAI este comandant de pluton în cadrul Centrului de Comandă și Control pentru Operare Aeriană, Veszprem, Ungaria.E-mail: info@zsrobert.com 


\section{Introducere}

Problematica dezastrelor și a situațiilor de criză rămâne un subiect de continuă actualitate, care presupune un efort conjugat ce implică resurse umane și materiale deosebite; de aceea sunt necesare metode speciale pentru a le putea preveni. Dezastrele, evenimentele catastrofale şi nevoia de protecție împotriva lor apar permanent. Semnificația termenului ,catastrofă”, de origine greacă, este un punct de cotitură sau un rezultat, dar oamenii i-au atribuit înțelesul de nenorocire sau stare de criză. O caracteristică importantă a dezastrelor naturale soldate cu victime este că apariția lor nu poate fi prezisă cu precizie sau frecvență, de obicei se întâmplă destul de neașteptat, ceea ce face ca încercările de contracarare să fie mai dificile.

Recent, a fost dezvoltată Legea maghiară nr. CXXVIII din 2011, privind managementul dezastrelor și modificările aduse anumitor acte conexe, care este definitorie în ceea ce privește noțiunea de dezastru. Conform Secțiunii 3, clauza 5, hazardul este o condiție sau situație potrivită pentru declararea stării de urgență sau pentru a nu ajunge la declararea unei astfel de situații, dar care pune în pericol în mod clar viața oamenilor, sănătatea acestora, valorile materiale și mediul înconjurător într-o societate, într-o asemenea măsură încât prevenirea sau gestionarea acestuia depășesc posibilitățile și capacitățile organizațiilor juridice și necesită, astfel, cooperarea continuă și strict coordonată a organismelor guvernamentale și utilizarea sprijinului internațional. Datorită gestionării dezastrelor, s-a impus necesitatea stabilirii unui sistem de protecție și prevenire reglementat prin lege. Din cauza diversității sarcinilor, a devenit necesară reînnoirea reglementării legale și a practicilor de gestionare a dezastrelor începând din ianuarie 2012, de la aderarea la Uniunea Europeană. Noua lege reglementează în mod cuprinzător domeniile de activitate și responsabilitățile aferente. Pentru a dispune de suficient timp în vederea planificării activităților înainte de producerea unor situații de urgență previzibile, Legea privind gestionarea dezastrelor introduce ,perioada de risc de dezastru”.

O situație de urgență, definită în articolul 53 din Constituția Ungariei, poate fi declanșată în special de următoarele evenimente (prevăzute în secțiunea 44 din noua Lege privind gestionarea dezastrelor):

- dezastre elementare, pericole naturale;

- accidente industriale, amenințări de origine umană;

- alte pericole, dezastre.

Astfel, în caz de urgență, pentru o anumită perioadă de timp, guvernul este în măsura să introducă reglementări suplimentare, pentru o anumită regiune, în conformitate cu Cat. Paragrafele 47-48. De asemenea, conform Cat. Paragrafele 49-51, pot fi autorizate unele organizații, care să implementeze reglementările extraordinare menționare anterior. În timpul apariției unor situaţii de urgență, s-a dovedit că protecția împotriva acesteia nu revine doar în sarcina unei organizații 
speciale, ci, pentru sporirea șanselor de soluționare a unei asemenea situații, este necesară coordonarea și cooperarea organizațiilor guvernamentale naționale și locale și a organizațiilor nonguvernamentale.

La nivel internațional, o protecție eficientă depinde de Națiunile Unite, Uniunea Europeană și NATO. Mai mult, la nivel local, în Ungaria, aceasta depinde și de cooperarea organizațiilor caritabile și de cea a bisericilor. Crearea și menținerea siguranței, precum și dezvoltarea planurilor de gestionare a dezastrelor reprezintă un element de comun foarte important. Caracteristicile sarcinilor şi specificul abilităților diferitelor organizații implicate reprezintă, astfel o asigurare pentru pregătirea eficientă, reducerea consecințelor negative în timpul protecției și recuperarea în urma dezastrelor sau a situațiilor de urgență. Dezastrele și nevoia populației de a se proteja împotriva acestora pot apărea în orice moment. Sistemul de management al apărării și rolul autorităților sunt esențiale pentru gestionarea și coordonarea intervenției în caz de urgență, deoarece este datoria lor legală să aibă grijă de populația afectată de un astfel de eveniment.

\section{Efectele psihologice ale dezastrelor}

Caracteristica generală a situațiilor de urgență este distrugerea pe scară largă, ceea ce provoacă pierderi semnificative. Majoritatea unor astfel de situații se întâmplă în mod neașteptat, astfel că sentimentele de nesiguranță și vulnerabilitate ale celor implicați sunt prezente într-o manieră explicită. Trăirea dezastrelor în mod direct sau pe baza informațiilor indirecte poate conduce la o situație stresantă și frustrantă, în același timp. O situație de urgență este o situație specială, care afectează în mod direct atât pe cei care au trăit-o, cât și personalul care a intervenit pentru gestionarea sa. Pe baza dovezilor empirice ale zonelor afectate de dezastru, populația pregătită din punct de vedere psihologic suferă pierderi semnificativ mai mici, deoarece comportamentul corect explicat, cunoașterea posibilităților de autosalvare și capacitatea de a coopera cu forțele de intervenție pot fi cruciale în caz de urgență. Numărul tot mai mare de lucrări de specialitate și de cercetări empirice subliniază necesitatea pregătirii psihologice atât a civililor, cât și a personalului de intervenție. În ceea ce privește fenomenele psihologice care însoțesc dezastrele, s-a susținut că panica este mecanismul natural care intervine în situația de urgență și acționează chiar dacă nu este luată în considerare. În unele cazuri, un act sau o declarație spontană vor contribui la normalizarea situației, dar în alte cazuri, același act poate provoca o stare de panică. Prezentarea rapidă, recunoașterea situației și, eventual, experiența anterioară pot juca un rol cheie în prevenirea sentimentului de panică. Numeroase metode de sprijin psihosocial permit asistență adaptată nevoilor individuale și comunitare. Bunăstarea psihosocială poate fi considerată nevoia de bază și, dacă acest lucru se deteriorează, este necesară stabilizarea acesteia. 
Procesarea dezastrelor și efectelor lor psihologice și sociale sunt diferite pentru fiecare om în parte. Personalul de prim ajutor ar putea avea nevoie de sprijin pentru a procesa lucrurile la care asistă în timpul unei intervenții, la fel și populația care trece prin situația de criză și așteaptă ajutor. În general, nu este încă un lucru obișnuit ca oamenii să împărtășească problemele lor emoționale, mentale sau psihologice cu un necunoscut. Acest fapt este adesea tratat ca fiind un semn de slăbiciune, precum și un indiciu că un individ nu este capabil să facă față situației pe cont propriu. Dacă pericolul este prezis, poate exista o teamă excesivă de ameninţare în faza de predezastru. Pe timpul producerii situației de urgență, familia deține un rol important în ceea ce privește acordarea sprijinului emoțional, contribuind la procesarea fricilor, eșecurilor și rănilor și la reducerea situațiilor stresante și ameliorarea tensiunii ${ }^{1}$. Frica este o stare emoțională esențială pentru apărarea organismului, motivează și încurajează oamenii să acționeze și poate declanșa reacții de supraviețuire. $\mathrm{O}$ caracteristică importantă a acestei etape este aceea că indivizii, chiar și la nivel inconștient, tind să adopte o atitudine gregară. Din cauza elementului surprinzător al evenimentului declanșat, frica poate afecta individul ca un şoc, iar efectul evenimentului neașteptat s-ar putea întipări în personalitatea și experiența celor implicaţi. În plus, repercusiunile dezastrelor devin vizibile și evaluabile la câteva zile, săptămâni sau luni după producerea evenimentului ${ }^{2}$. Aceste efecte pot produce anxietate, fobii sau credințe iraționale. Pe de altă parte, experiența de a face față fricii de succes poate crea, de asemenea, noi abilități durabile și noi tehnici de adaptare. Este necesară o comunicare clară și simplă cu o persoană aflată într-o situație de criză. Expresia emoției deschise, manifestarea evenimentelor prezente, trecute și viitoare pot concentra focalizarea persoanei asupra problemei reale. Este necesară transparența în comunicarea de criză, dar, acolo unde este cazul, este de dorit ca anumite informații să nu fie divulgate populației, pentru a preveni panica ulterioară. Personalul de intervenție se poate confrunta cu problema empatiei ca fiind o barieră. Explorarea realistă, managementul asumat, leadershipul, intervenția profesională, investițiile în echipamente de salvare, comunicarea credibilă pot avea o influență decisivă asupra activității, vitezei și abilităților de rezolvare a problemelor ale personalului de intervenție. În plus, numeroase studii de caz concluzionează că ajutorul ar trebui să fie proactiv, întrucât persoanele care au trecut printr-o situație de criză nu vor solicita ajutor, deoarece starea lor mentală actuală nu le va permite să aibă un comportament coerent ${ }^{3}$. De asemenea, specialiștii care doresc să ajute în situații de dezastru sau de criză trebuie să dețină cunoștințe psihologice care pot contribui la creșterea sentimentului de securitate al indivizilor. Viețile oamenilor

\footnotetext{
${ }^{1}$ Albert-Farkas Leveleki, Szociológia, Editura Möbius Print, Nyíregyháza, 2001, p. 114.

2 ***, Segitségnyújtás katasztrófa és terrortámadás esetén - Belga Vöröskereszt kiadványa, Eureste Handbook, Brüsszel, 2006, ISBN 2-930434-16.3.

${ }^{3}$ Internation of Red Cross: Enhancing psychological support, IFRC, Geneva, 2007.
} 
sunt puse în pericol în zonele afectate de dezastre. Oamenii se pot răni sau, mai rău, pot deceda. În plus, nu se poate trece cu vederea faptul că supraviețuitorii se află sub o presiune psihologică semnificativă, care poate avea consecințe grave mai devreme sau mai târziu, cu repercusiuni pentru restul vieții lor ${ }^{4}$. Conform abordării psihologice a dezastrelor, o catastrofă este un eveniment devastator din punct de vedere psihologic, care se află în afara gamei de experiențe umane obișnuite, care poate duce la reacții comportamentale anormale, cu anumite simptome specifice ${ }^{5}$. În multe cazuri, experiențele neprocesate din punct de vedere spiritual revin în memorie și pot îngreuna viaţa cotidiană din cauza laturii lor deprimante.

Panica în masă este o formă specifică de comportament comunitar care agravează foarte mult și chiar împiedică fuga și supraviețuirea indivizilor și, totodată, îngreunează munca salvatorilor ${ }^{6}$. De exemplu, imediat după dezastrul scufundării navei de croazieră Titanic, principiul moral de bază al acordării priorității salvării femeilor, copiilor și persoanelor în vârstă a dispărut destul de repede. Unii bărbați au încercat să găsească un loc în bărcile de salvare, deghizându-se în femei, alții au încercat să obțină o vestă de salvare sub amenințarea cuțitului ${ }^{7}$. Caracteristicile comune ale persoanelor aflate în stadiul de panică sunt pierderea judecății și izbucnirile emoționale extreme. De asemenea, pierderea controlului moral și nerespectarea normelor comunitare sunt frecvente în astfel de situații de panică. În alte cazuri, de exemplu, într-un accident rutier soldat cu mai multe decese, în rândul personalului de intervenție se pot observa elemente de depresie, apariţia sentimentului de neajutorare, vinovăţie și anxietate cu privire la eșec ${ }^{8}$.

În ceea ce privește forțele naționale de apărare și de gestionare a dezastrelor, membrii personalului de intervenție reușesc, în cele mai multe situații, să depășească frica și alte sentimente deprimante, dar există cei a căror stabilitate mentală nu revine la poziția inițială de echilibru, deoarece resursele lor au fost alterate ca urmare la diferitele reacții la stres. În cazul lor, este necesară intervenția în caz de crizăg; aceasta vizează rezolvarea unei situații de criză cu intenția de a fi de ajutor.

\footnotetext{
${ }^{4}$ Zsuzsanna Kaló, A korai és késői pszichés jelenségek katasztrófák során, és a káros hatások elkerülésének lehetséges módjai, Müszaki Katonai Közlöny, XXI. évf. 12. sz. különszám, Budapesta, 2011, NKE HHK MHTT, Müszaki Szakosztály, URL: http://www.hhk.uni-nke.hu/downloads/ kiadvanyok/mkk.uni-nke.hu/eloadasokpdf/3.csop/Kalo\%20Zsuzsanna.pdf, accesat la 25.04.2014. ${ }^{5}$ Judit Bolgár, György Szekeres, Katasztrófa és kríziskommunikáció lélektani alapjai. Elektronikus jegyzet a Védelem Igazgatás szereplöi számára, Bp.: ZMNE. 2009. URL: URL: https://adoc.pub/ katasztrofa-es-kriziskommunikacio-lelektani-alapjai.html, accesat la 25.04.2021.

${ }^{6}$ Róbert Zsákai, ”A lelki segítségnyújtás jelentősége katasztrófák során”, URL: https://www.knbsz. gov.hu/hu/letoltes/szsz/2014_1_szam.pdf, accesat la 06.07.2021.

${ }^{7}$ Iván Kéménczy, Tömegkatasztrófák pszichológiai hatásai, Zrínyi Katonai Kiadó, Budapesta, 1980, pp. 31-32.

${ }^{8}$ Dr. Róbert Barlai, György Kővágó, Válság-(katasztrófa) kommunikáció, Petit Real Könyvkiadó, Budapesta, 1996, p. 31.

${ }^{9}$ Zelimir Pavlina, Zoran Komar, Katonapszichológia I-III, Editura Zryni, 2007.
} 
Crizele se caracterizează prin anxietate și frică. Câteva boli psihice sunt cunoscute ca având la bază o afecțiune psihiatrică ale cărei caracteristici nu s-au schimbat de-a lungul timpului. Depresia este o problemă universală care poate fi resimțită fie de persoane rănite, fie de cei care intervin în situații de urgență, manifestarea acesteia fiind posibilă chiar și după depăşirea situației de criză. De regulă, depresia este o afecțiune tranzitorie care persistă pentru o perioadă scurtă de timp, cu condiția ca persoana în cauză să își stabilizeze starea mentală și să își schimbe modul de gândire despre sine și despre problema respectivă ${ }^{10}$. Diagnosticul bolii se bazează pe o examinare a stării psihice a pacientului și, deși tratamentele medicale se îmbunătățesc continuu, din păcate, medicii caută în permanență o modalitate cu adevărat eficientă de a vindeca depresia. Problematica asistenței psihologice oferă o oportunitate excelentă de explorare a domeniului, deoarece dacă sănătatea mentală a oamenilor se deteriorează, sunt periclitate: soluția problemelor, gestionarea dezastrului, crizei, precum și eliminarea consecințelor sale.

\section{Soluții naționale și internaționale pentru gestionarea dezastrelor}

Mediul în continuă schimbare solicită individului, organizației și grupului să se adapteze rapid din punct de vedere profesional. Dezastrul infam provocat de revărsarea noroiului roșu toxic din Ungaria, care a avut loc la 4 octombrie 2010, a fost cel mai grav accident ecologic și industrial din istoria modernă a acestei țări. Dezastrul cauzat de deteriorarea bazinului unei uzine de prelucrare a aluminiului din MAL Zrt. a provocat pagube materiale în zonă și pierderi de vieți omenești, precum și alterarea mediului înconjurător, poluând terenurile agricole și căile navigabile. În timpul gestionării evenimentelor, cooperarea dintre ministere, contribuția sectorului construcțiilor, a organizațiilor naționale și a oamenilor de știință s-au dovedit remarcabile. Dezastrul a mobilizat o masă socială foarte importantă ${ }^{11}$. Era evident faptul că gestionarea dezastrelor se află în fruntea asistenței psihologice în îndeplinirea sarcinilor de protecție civilă, siguranță industrială și protecție împotriva incendiilor. În cazul dezastrului cu noroi roșu toxic, organizațiile umanitare au contribuit cu un sprijin suplimentar față de organizațiile profesionale și naționale, întrucât acestea au efectuat donații semnificative în bani, servicii, au oferit sprijin psihologic celor afectați, au contribuit la furnizarea de materiale pentru construirea de case noi, cu rolul de a sprijini victimele dezastrului ecologic. La nivel local, regional și național, forțele de gestionare a dezastrelor trebuie să sprijine activitățile de pregătire și protecție a populației, precum și să participe la planificarea, organizarea și implementarea sarcinilor de recuperare. În caz contrar, atunci când

${ }^{10}$ Tim Lahaye, Gyözelem a depresszió felett, Budapesta, 1998, p. 243.

${ }^{11}$ Árpád-PAPP Antal Muhoray, A vörösiszap-katasztrófa elleni védekezés, a helyreállitás, újjáépités tapasztalatai, II. Belügyi Szemle,61.évf. 3.sz. 2013. pp. 84-85. 
se confruntă cu o criză, organizațiile de sprijin și armata ar trebui să se coordoneze reciproc și să coopereze pentru a livra în siguranţă provizii și materiale necesare la locul dezastrului. Cooperarea CIMIC (civili-militari) are un rol important de jucat în utilizarea resurselor, sprijinirea misiunilor umanitare și asigurarea succesului operațiunilor militare ${ }^{2}$. Organizațiile internaționale și naționale pot avea ca scop oferirea de ajutor în caz de dezastre, la solicitarea guvernelor statelor aflate în primejdie, cu aprobarea guvernului țării care acordă sprijin, precum a fost cazul guvernului maghiar în 2021, la solicitarea guvernului croat, în urma unui cutremur important petrecut în apropierea orașului Petrinja.

În concluzie, scopul este de a salva vieți omenești și bunuri materiale în fiecare caz, dar și acela de a mobiliza resurse materiale și resurse umanitare. Diferite organizații nonguvernamentale, asociații și lăcașuri de cult (biserici) joacă un rol important, inclusiv în cazul persoanelor afectate de dezastre, oferind sprijin prin măsuri practice, asistență socială și juridică. De asemenea, oferă asistență psihosocială și mentală părților interesate și, dacă este necesar, populația afectată este direcționată către un psiholog sau către alt profesionist în domeniu ${ }^{13}$. Fiecare organizație ar trebui să ofere sprijin atât cât este posibil. Spre exemplu, în cazul deja menționat cu reversarea de nămol roșu, transmisia unui post de radio local s-a efectuat din biserica din orașul Devecser, acest mijloc de comunicare contribuind la informarea populației locale, iar biserica a jucat un rol imens în distribuirea donațiilor primite. În cadrul bisericii din Kolontar, împreună cu colegii militari, au fost organizate spații pentru odihnă pentru personalul de intervenție, pe timp de noapte, în perioada inițială de gestionare a operațiunilor de salvare. Pentru a înțelege efectele psihologice, este necesar de știut care sunt fenomenele care însoțesc și contribuie la declanșarea unui efect psihic negativ într-o situație de dezastru. Analizând evenimentele unui dezastru, pot fi identificate unele fenomene însoțitoare care ar trebui să fie întotdeauna luate în considerare în aceste zone. ${ }^{14}$ Dacă simptomele asociate cu anxietatea apar în termen de patru săptămâni de la evenimentul traumatic și durează între două și 28 de zile, se poate considera că persoana în cauză suferă de tulburare de stres acut ${ }^{15}$. De aceea este necesar ca o echipă formată din psihiatri, psihologi, preoți și apropiați să le ofere ajutor celor care au nevoie, în zonele afectate de dezastru. Frica este o stare emoțională esențială pentru supraviețuire, întrucât contribuie la evitarea pericolului prin declanșarea unor reacții instinctive. Anxietatea existențială este o frică generală a omului, care

12 József Padányi,Polgári-katonai együttmüködés a békefenntartó müveletek során, ZMNE, Budapesta, 2001, p. 6.

${ }^{13}$ E. Raquel Cohen, Pan American Health Organization: Mental health services in disasters: manual for humanitarian workers, PAHO, 2000, p. 223.

${ }^{14}$ Dr. Júlia Hornyacsek, A települési védelmi képességek a katasztrófakihívások tükrében, Oktatási és Tanácsadó Tudományos Egyesület, 2011, Budapesta, pp. 40-42.

${ }^{15}$ J. Ronald Comer, A lélek betegségei, Editura Osiris Kiadó, Budapesta, 2000, p. 205. 
rezultă din limitările și responsabilitățile existenței noastre. Suntem anxioși pentru că recunoaștem faptul că viața nu este infinită și moartea este inevitabilă ${ }^{16}$.

Bisericile nu sunt comunități politice, ci, în primul rând, ele sunt comunităti spirituale. Experiența demonstrează faptul că enoriașii sunt, în general, mai stabili din punct de vedere mental, mai puțin predispuși la panică în timpul situațiilor de urgență și pot fi implicați cu mai multă ușurință în acordarea de prim ajutor. Când se întâmplă un dezastru, credincioșii tind să gestioneze situația cu mai multă speranță, în pofida dificultăților. Pe baza cercetărilor, oamenii sunt, de asemenea, foarte influențați de cultura unei anumite țări. Cunoașterea și înțelegerea culturii locului respectiv înseamnă că toată lumea poate și are un rol de jucat în crearea și menținerea siguranței, inclusiv a lăcașelor de cult ${ }^{17}$. De-a lungul istoriei, în timpul celor mai mari pericole, bisericile au fost întotdeauna acolo pentru a acorda sprijin oamenilor care au avut nevoie, indiferent prin ce dezastru sau dificultate au trecut. Adesea, partea cea mai dificilă pe care o trăiește personalul de intervenție este departe de a fi de ordin material. Atenția personală, puterea comunității, consilierea tactică și personală, îngrijirea socială sunt elemente fundamentale ale activităților bisericești și de ordin religios.

\section{Concluzii}

Măsurarea riscului și a rezilienței este un instrument important pentru înțelegerea vulnerabilității oamenilor în situații de dezastru, iar rezultatele acestora ar trebui incluse în măsurile pentru planificarea de urgență. Activitățile de prevenție și reducere a dezastrelor reprezintă o provocare majoră, care necesită o capacitate semnificativă la nivel local, dar în același timp ar trebui să facă parte dintr-o strategie cuprinzătoare. Stilul nostru de viaţă din ultimii ani poate reprezenta un motiv de teamă constantă. Apariția epidemiilor, lupta permanentă împotriva dezastrelor, terorismul reprezintă probleme cu care ne confruntăm în mod frecvent. Pandemia de COVID-19 a adus o notă de incertitudine și nesiguranță în viețile oamenilor. Anxietatea, fricile, sentimentele de neputință au devenit o povară din ce în ce mai mare asupra indivizilor. Cadrele medicale împreună cu armata au o mare responsabilitate și se poate observa că cei care lucrează în linia întâi în lupta împotriva pandemiei de COVID-19 au un rol din ce în ce mai important de jucat. Și ei pot fi afectați de pandemie, ale cărei efecte sunt asemănătoare cu cele din timpul dezastrelor naturale sau din zonele de război. Rezultate științifice recente demonstrează că recunoașterea aspectelor legate de gestionarea dezastrelor în

\footnotetext{
${ }^{16}$ J. Ronald Comer, A lélek betegségei. Pszichopatológia, Editura Osiris Kiadó, Budapesta, 2005, p. 160.

${ }^{17}$ István Bukovics, Gondolatok az egyházak szerepéről a katasztrófavédelemben, Editura Wesley János Lelkészképző Főiskola kiadványa, Budapesta, 2008, pp. 1-5.
} 
ceea ce privește asistența psihologică devine din ce în ce mai necesară. Experiența ultimilor ani scoate în evidență faptul că dezastrele și situațiile de criză au devenit parte integrantă a vieții noastre. Aceste situații nu pot fi evitate, dar efectele lor pot fi diminuate, având specialiști cu o pregătire temeinică în acest sens. Este suficient să ne gândim la evenimentele din 11 septembrie 2001 sau să ne amintim de inundațiile și evenimentele meteorologice extreme din ultimii ani, sau de dezastrul revărsării noroiului roșu din Ungaria. Un atac terorist a provocat regândirea sistemului de apărare al comunitătii europene, făcând necesare reconsiderarea și stabilirea unei strategii de apărare la nivel comunitar și global. A devenit clar faptul că gestionarea dezastrelor nu este doar o problemă tehnică sau juridică, ci o problemă socială complexă în care trebuie luate în considerare cazuri și proceduri speciale, toate acestea fiind confirmate de evenimentele internaționale din ultimii ani. Oamenii nu trebuie lăsați într-o stare de vulnerabilitate și nesiguranță. Procesele catastrofale și de panică menționate anterior, împreună cu comunicarea inadecvată pot sta la bază și pot genera consecințele dezastruoase ale situațiilor de criză. Astfel, tot mai mulți oameni contribuie la procesul complex de gestionare a crizelor, pe lângă coordonarea gestionării de către profesioniști a dezastrelor. Dacă comunitățile vulnerabile sunt mai conștiente de riscuri și cunose strategiile de bază pentru a face față situațiilor, acestea pot reduce la minimum numărul de decese și pierderi materiale, precum și eventualele vătămări psihice. Companiile naționale pot încuraja înființarea Comitetelor de urgență comunitare, responsabile de planificarea, gestionarea și coordonarea activităților de răspuns și pregătire.

De asemenea, bisericile joacă un rol important în ajutorarea celor afectați de o situație catastrofală, întrucât religia este parte importantă din viața multor oameni. Prin urmare, bisericile sunt bine adaptate structurii lor organizaționale și misiunii și contribuie activ la gestionarea situațiilor de criză. Ceea ce societatea se așteaptă este ca evenimentele dramatice să fie gestionate în mod profesional, uman și cu suficientă empatie de către organizațiile dedicate acestui lucru. Se constată faptul că, în ultimele decenii, bisericile au trecut printr-o transformare destul de mare, de exemplu, modul în care este manifestată credința sau chiar în organizarea lor structurală, însă valorile lor au rămas aceleași de-a lungul timpului, și totul se rezumă la a proteja cea mai mare valoare, și anume: viața oamenilor. În trecut, conducătorii militari puteau fi pregătiți doar pentru a lua decizii rapide, dar, în prezent, cooperarea eficientă cu organizațiile civile, guvernamentale și nonguvernamentale reprezintă o prioritate pentru conducerea militară. Lansarea unui program detaliat de cercetare care implică bisericile, bazat și pe faptul că îndeplinirea rolului de gestionare a dezastrelor este o cerință națională și socială, trebuie să fie flexibilă la diferite schimbări naturale.

Prevenirea presupune întotdeauna mai puține cheltuieli decât gestionarea și recuperarea în urma unui dezastru sau a unei situații de urgență. Fiecare ocazie ar trebui fructificată pentru a reduce la minimum daunele provocate prin prognozarea 
fiecărui tip de dezastru, pentru a consolida cooperarea diferitelor organizații și pentru a ajuta și a instrui populația în vederea gestionării unei situații de dezastru.

Lupta împotriva coronavirusului este foarte asemănătoare cu medicina practicată pe câmpul de luptă, definită de psihologia militară prin sintagma „pacienții disperați”, iar lupta cu un dușman invizibil și mediul înconjurător riscant sunt mult mai rele decât un război. Apariția și răspândirea globală a virusului SARS-CoV-2 a demonstrat cât de mult se poate împovăra societatea și economia și cât de pregătiți sunt cei care activează în domeniul asistenței medicale, dar și în alte domenii, pentru o astfel de gestionare a problemelor. $\mathrm{Nu}$ știm exact care este inamicul real, însă cu toții resimțim o presiune psihică uriașă, ne confruntăm cu posibilitatea de a pierde pe cineva apropiat, dar și cu mult pericol. Epuizarea fizică și mentală extremă poate fi cauzată de o mulțime de vești proaste, care pot duce la dereglări psihice. Potrivit specialiștilor, atât în rândul populației, cât și în rândul cadrelor medicale, forțelor armate, personalului de pe ambulanțe sau personalului militar apar din ce în ce mai multe probleme de natură psihologică. Efortul zilnic constant, temerea de infectare, numărul de decese și sentimentul de neputinţă pot provoca traume emoționale care pot duce la probleme psihice grave. În multe cazuri, confuzia se poate transforma în tulburare de stres posttraumatic (PTSD). Anxietatea poate avansa spre depresie, dar poate duce și la epuizarea rapidă, astfel încât cei în cauză pot deveni ușor victime, din punct de vedere psihologic. Termenul „a doua victimă” îi aparține lui Albert Wu, profesor la Universitatea Johns Hopkins din Baltimore. Potrivit cercetărilor științifice ale lui $\mathrm{Wu}$, cei aflați în prima linie de ajutorare a celor afectați de pandemie ar trebui să acorde atenție sporită tratării stării emoționale și psihice a pacientului, deoarece PTSD este un sindrom insidios care poate persista mai mult timp și poate duce la o retrăire a evenimentelor de către acesta. Sentimentul de neputință îi este indus pacientului prin conștientizarea constantă a repercusiunilor negative (decese) ale pandemiei. Prezența fizică a angajaților și îngrijorarea acestora că ar putea contracta virusul în orice moment, sau că ar putea reprezenta un pericol pentru cei dragi, prin infectare, adaugă o presiune psihică uriașă asupra acestora. De asemenea, cadrele militare care sprijină activ personalul medical, se confruntă cu probleme similare, întrucât nu există nicio garanție că își vor păstra sănătatea în tot acest proces. Considerăm că, pe lângă dezvoltarea capacităților militare clasice, reziliența este un domeniu în care este necesară pregătirea planificată și coordonată pentru a garanta securitatea unei țări și acesta este un domeniu care trebuie dezvoltat, implicând mai multe resurse umane și materiale. Elementele importante sunt: pregătirea, stocarea resurselor, dezvoltarea strategiei și efectuarea de simulări premergătoare situațiilor de criză. În absența lor, este puțin probabil ca forța militară să fie suficientă pentru a face față situațiilor de criză în mod optim. Sprijinul psihologic, cu accent pe componenta emoțională, este necesar pentru a păstra sănătatea psihică a tuturor angajaților din sistemul medical 
și sistemele conexe. Serviciile de asistență psihologică sunt binevenite, întrucât dacă sănătatea psihică a angajaților se deteriorează, situația de criză și eliminarea consecințelor acesteia sunt periclitate.

\section{BIBLIOGRAFIE:}

1. ***, Internation of Red Cross: Enhancing psychological support, IFRC, Geneva, 2007.

2. ***, Segitségnyújtás katasztrófa és terrortámadás esetén - Belga Vöröskereszt kiadványa, Eureste Handbook, Brüsszel, 2006, ISBN 2-930434-16.3

3. BARLAI, Róbert; KÖVÁGÓ, György, Válság-(katasztrófa) kommunikáció. Petit Real Könyvkiadó, Budapesta,1996.

4. BOLGÁR, Judit; SZEKERES, György, Katasztrófa és kríziskommunikáció lélektani alapjai. Elektronikus jegyzet a Védelem Igazgatás szereplöi számára, Bp.: ZMNE, 2009, URL: https://adoc.pub/katasztrofa-es-kriziskommunikacio-lelektanialapjai.html

5. BUKOVICS, István, Gondolatok az egyházak szerepéről a katasztrófavédelemben, Editura Wesley János Lelkészképző Főiskola kiadványa, Budapesta, 2008.

6. COHEN, E. Raquel, Pan American Health Organization: Mental health services in disasters: manual for humanitarian workers, PAHO, 2000.

7. COMER, J Ronald, A lélek betegségei. Pszichopatológia, Editura Osiris Kiadó, Budapesta, 2005.

8. COMER, J Ronald., A lélek betegségei, Editura Osiris Kiadó, Budapesta, 2000.

9. Dr. HORNYACSEK, Júlia, A települési védelmi képességek a katasztrófakihívások tükrében, Oktatási és Tanácsadó Tudományos Egyesület, Budapesta, 2011.

10. FISCHL, Vilmos, A nemzetközi egyházi szervezetek szerepe az államközi valamint csoportok közötti konfliktusok és válságok kezelésében, Budapesta, ZMNE Doktori (Phd) értekezés, 2006.

11. KÁDÁR, Pál, A pandémia kezelése mint a nemzeti ellenálló képesség „tesztje”, Honvédségi Szemle 149.évfolyam 2021/2.

12. KALÓ, Zsuzsanna, A korai és késői pszichés jelenségek katasztrófák során, és a káros hatások elkerülésének lehetséges módjai, MÜSZAKI KATONAI KÖZLÖNY, XXI.évf.12. sz. különszám, 2011. Budapesta, NKE HHK MHTT, Müszaki Szakosztály, URL: http://www.hhk.uni-nke.hu/downloads/ kiadvanyok/ mkk.uni-nke.hu/eloadasokpdf/3.csop/Kalo\%20Zsuzsanna.pdf

13. KÉMÉNCZY, Iván, Tömegkatasztrófák pszichológiai hatásai, Zrínyi Katonai Kiadó, Budapesta, 1980. 
14. LAHAYE, Tim, Gyözelem a depresszió felett, Budapesta, 1998.

15. LEVELEKI,Albert-Farkas, Szociológia, Editura Möbius Print, Nyíregyháza, 2001.

16. MUHORAY, Árpád, A 2001-es beregi árvíz tizedik évfordulóján túl. Belügyi szemle, 60 évf. 2012/9.

17. MUHORAY, Árpád-PAPP Antal, A vörösiszap-katasztrófa elleni védekezés, a helyreállitás, újjáépités tapasztalatai, II. Belügyi Szemle, 61 évf. 3. sz. 2013.

18. PADÁNYI, József, Polgári-katonai együttmüködés a békefenntartó müveletek során, ZMNE, Budapest, 2001.

19. ZORINÁCZ, Ádám, Egyházak a katasztrófavédelmi feladatrendszerben. (MÜSZAKI KATONAI KÖZLÖNY, XXI. évf. 12. különszám, Budapesta, 2011, NKE HHK MHTT) URL: http://hhk.uninke.hu/downloads/kiadvanyok/mkk.uninke. hu/eloadasokpdf/3.csop/Zorinacz\%20Adam.pdf

20. ZSÁKAI, Róbert, “A lelki segítségnyújtás jelentősége katasztrófák során”, URL: https://www.knbsz.gov.hu/hu/letoltes/szsz/2014_1_szam.pdf

Traducere din limba engleză: Andreea Tudor 